\title{
Comparison of sub-chronic metabolic effects of stable forms of naturally occurring GIP(1-30) and GIP(1-42) in high-fat fed mice
}

\author{
Victor A Gault, David W Porter, Nigel Irwin and Peter R Flatt \\ School of Biomedical Sciences, SAAD Centre for Pharmacy and Diabetes, University of Ulster, Coleraine BT52 1SA, UK \\ (Correspondence should be addressed to N Irwin; Email: n.irwin@ulster.ac.uk)
}

\begin{abstract}
Glucose-dependent insulinotropic polypeptide (GIP) is a 42 amino acid hormone secreted from intestinal K-cells, which exhibits a number of actions including stimulation of insulin release. A truncated form, GIP(1-30), has recently been demonstrated in intestine and islet $\alpha$-cells. To evaluate the potential physiological significance of this naturally occurring form of GIP, the present study has examined and compared the bioactivity of enzymatically stabilised forms, [D-Ala ${ }^{2}$ $\operatorname{GIP}(1-30)$ and $\left[\mathrm{D}-\mathrm{Ala}{ }^{2}\right] \mathrm{GIP}(1-42)$, in high-fat fed mice. Twice-daily injection of GIP peptides for 42 days had no significant effect on food intake or body weight. However, non-fasting glucose levels were significantly lowered, and insulin levels were elevated in both treatment groups compared to saline controls. The glycaemic response to i.p. glucose was correspondingly improved $(P<0 \cdot 05)$ in $\left[\mathrm{D}-\mathrm{Ala}^{2}\right] \mathrm{GIP}(1-30)-$ and $\left[\mathrm{D}-\mathrm{Ala}^{2}\right] \mathrm{GIP}(1-42)$-treated mice.
\end{abstract}

Furthermore, glucose-stimulated plasma insulin levels were significantly elevated in both treatment groups compared to control mice. Insulin sensitivity was not significantly different between any of the groups. Similarly, plasma lipid profile, $\mathrm{O}_{2}$ consumption, $\mathrm{CO}_{2}$ production, respiratory exchange ratio, and energy expenditure were not altered by 42 days twicedaily treatment with $\left[\mathrm{D}-\mathrm{Ala}^{2}\right] \mathrm{GIP}(1-30)$ or $\left[\mathrm{D}-\mathrm{Ala}^{2}\right] \mathrm{GIP}(1-42)$. In contrast, ambulatory activity was significantly $(P<0 \cdot 05)$ elevated during the light phase in both GIP treatment groups compared to saline controls. The results reveal that sustained GIP receptor activation exerts a spectrum of beneficial metabolic effects in high-fat fed mice. However, no differences were discernable between the biological actions of the enzyme-resistant analogues of the naturally occurring forms, GIP(1-30) and GIP(1-42).

Journal of Endocrinology (2011) 208, 265-271

\section{Introduction}

Glucose-dependent insulinotropic polypeptide (GIP) is a 42 amino acid gastrointestinal hormone secreted from K-cells that performs a spectrum of biological activities through activation of GIP receptors on target cells (McIntosh et al. 2009). Thus, in addition to classically inhibiting gastric acid secretion, GIP has been shown more recently to exert positive effects on adipocyte metabolism, remodelling of bone and cognition (Irwin et al. 2010). Despite these advances, the most widely recognised role of GIP is as an important glucosedependent stimulator of insulin secretion from pancreatic $\beta$-cells (Pederson \& Brown 1976). Studies indicate that conservation of the $\mathrm{N}$-terminal amino acid sequence produces GIP peptides that retain insulinotropic action. In agreement with this, GIP(1-30) has been shown to exhibit equal insulin-releasing potencies in the perfused rat pancreas when compared to GIP(1-42) (Pederson et al. 1990).

Recent studies by Fujita et al. (2010a) have highlighted potential differential posttranslational processing of GIP in gut $\mathrm{K}$-cells. Thus, processing of the precursor protein pro-GIP by prohormone convertase $1 / 3(\mathrm{PC} 1 / 3)$ is known to yield the full-length GIP(1-42) molecule (Ugleholdt et al. 2006).
However, PC2 immunoreactivity has been identified in a sub-population of K-cells, which appears to result in the generation of the truncated GIP isoform, GIP(1-30) (Fujita et al. 2010a). This distinct sub-set of cells represents $\sim 5-15 \%$ of the total GIP-immunoreactive cells in mice (Fujita et al. 2010a). Furthermore, immunohistochemical studies suggest that GIP is expressed in pancreatic islet $\boldsymbol{\alpha}$-cells and its secretion is under the control of $\mathrm{PC} 2$, again yielding the GIP(1-30) isoform (Fujita et al. 2010b). This bioactive form of GIP differs from the PC1/3-derived form secreted from K-cells. Therefore, GIP(1-30) appears to be a naturally occurring biologically active form, as well as GIP(1-42).

However, rapid degradation of the $\mathrm{N}$-terminal region of GIP poses a major obstacle in studying native peptides to delineate biological effects in vivo. Thus, GIP is rapidly metabolised by the ubiquitous enzyme dipeptidylpeptidase IV (DPP IV) to release the N-terminal dipeptide $\mathrm{Tyr}^{1}-\mathrm{Ala}^{2}$, giving rise to a biologically inactive fragment (Deacon et al. 2006). However, N-terminally modified analogues of GIP have profound resistance to DPP IV-mediated degradation, such as $\left[\mathrm{D}-\mathrm{Ala}^{2}\right]$ GIP (Hinke et al. 2002, Widenmaier et al. 2010). This form, with substitution of the natural $\mathrm{L}-\mathrm{Ala}^{2}$ for the $\mathrm{D}-\mathrm{Ala}^{2}$ isomer in GIP, has been shown in several studies to 
Table 1 Baseline characteristics of experimental mice. Values are means \pm S.E.M. for eight mice

\begin{tabular}{|c|c|c|c|}
\hline & $\begin{array}{l}\text { Saline } \\
\quad \text { controls }\end{array}$ & $\begin{array}{l}{\left[\mathrm{D}-\mathrm{Ala} \mathbf{a}^{2}\right]} \\
\quad \mathrm{GIP}(1-30)\end{array}$ & $\begin{array}{l}{\left[\mathrm{D}-\mathrm{Ala}{ }^{2}\right]} \\
\quad \operatorname{GIP}(1-42)\end{array}$ \\
\hline Daily food intake (g) & $4 \cdot 3 \pm 0 \cdot 2$ & $4 \cdot 3 \pm 0 \cdot 3$ & $4 \cdot 3 \pm 0 \cdot 4$ \\
\hline Body weight (g) & $57 \cdot 4 \pm 1 \cdot 3$ & $56 \cdot 8 \pm 2 \cdot 7$ & $57 \cdot 3 \pm 1 \cdot 6$ \\
\hline $\begin{array}{l}\text { Non-fasting plasma } \\
\text { glucose }(\mathrm{mmol} / \mathrm{l})\end{array}$ & $6 \cdot 7 \pm 0 \cdot 7$ & $6 \cdot 9 \pm 0 \cdot 6$ & $6 \cdot 7 \pm 0 \cdot 6$ \\
\hline $\begin{array}{l}\text { Non-fasting plasma } \\
\text { insulin }(\mathrm{ng} / \mathrm{ml})\end{array}$ & $1 \cdot 2 \pm 0 \cdot 6$ & $2 \cdot 0 \pm 0 \cdot 7$ & $1 \cdot 8 \pm 0 \cdot 8$ \\
\hline
\end{tabular}

Parameters were measured for 5 days prior to respective treatment regimens.

enhance insulin secretion in vitro and in vivo, mediating significantly improved glucose homeostasis in diabetic animal models (Hinke et al. 2002, Maida et al. 2009, Widenmaier et al. 2010).

In light of this, the present study has investigated and compared the biological effects of twice-daily administration of the enzymatically stable analogues of these two naturally occurring forms of GIP, namely $\left[\mathrm{D}-\mathrm{Ala}^{2}\right] \mathrm{GIP}(1-30)$ and $\left[\mathrm{D}-\mathrm{Ala}^{2}\right] \mathrm{GIP}(1-42)$, in high-fat fed mice. Given GIP(1-30) shares similar insulinotropic properties to the full-length molecule (Pederson et al. 1990), it is anticipated that the sub-chronic administration of $\left[\mathrm{D}-\mathrm{Ala}^{2}\right] \mathrm{GIP}(1-30)$ and $\left[\mathrm{D}-\mathrm{Ala}^{2}\right] \mathrm{GIP}(1-42)$ would recapitulate the well-established beneficial effects of prolonged GIP receptor activation on glucose homeostasis and insulin secretion in high-fat fed mice (Kerr et al. 2009). However, since GIP(1-30) is reportedly less potent in stimulating lipoprotein lipase activity than GIP(1-42) (Widenmaier et al. 2010), the GIP molecules may have diverse effects on circulating blood lipids. Finally, the present study examines the effects of 42-day administration of $\left[\mathrm{D}-\mathrm{Ala}^{2}\right] \mathrm{GIP}(1-30)$ and $\left[\mathrm{D}-\mathrm{Ala}^{2}\right] \mathrm{GIP}(1-42)$ on aspects of indirect calorimetry, which have never been investigated under situations of prolonged GIP receptor activation. Thus, we will firstly establish whether GIP(1-42) has effects on indirect calorimetry, and secondly if the biological effects of the truncated GIP metabolite are similar. To this end, the results of the present study demonstrate similar beneficial effects of prolonged GIP receptor activation by both GIP-based molecules in high-fat fed mice.

\section{Materials and Methods}

Peptides synthesis

$\left[\mathrm{D}-\mathrm{Ala}{ }^{2}\right] \mathrm{GIP}(1-30)$ and $\left[\mathrm{D}-\mathrm{Ala}^{2}\right] \mathrm{GIP}(1-42)$ were obtained from GL Biochem Ltd (Shanghai, People's Republic of China). Peptides were characterised using matrix-assisted laser desorption ionisation-time of flight (MALDI-TOF) mass spectrometry (Kerr et al. 2009). DPP IV resistance of $\left[\mathrm{D}-\mathrm{Ala}^{2}\right] \mathrm{GIP}(1-30)$ and $\left[\mathrm{D}-\mathrm{Ala}^{2}\right] \mathrm{GIP}(1-42)$ was confirmed as described previously (Kerr et al. 2009; data not shown).

\section{Animals}

NIH male Swiss TO mice (Harlan UK Ltd) were agematched, divided into groups and housed individually in an air-conditioned room at $22 \pm 2{ }^{\circ} \mathrm{C}$ with a $12 \mathrm{~h}$ light: $12 \mathrm{~h}$ darkness cycle (0800-2000 h). Experimental animals had free access to drinking water and a high-fat diet $(23 \cdot 6 \%$ fat, $21 \cdot 3 \%$ protein and $41 \cdot 2 \%$ carbohydrate; percentage of total energy of $19 \cdot 46 \mathrm{~kJ} / \mathrm{g}$; Special Diets Service, Essex, UK). Prior to commencement of studies, the experimental animals were maintained on high-fat diet from 6 weeks of age for 140 days. Obesity, insulin resistance, and hyperglycaemia were clearly manifested compared to similarly aged mice maintained on normal laboratory diet as judged by body weight, plasma insulin, and glucose analyses. All animal experiments were carried out in accordance with the UK Animals (Scientific Procedures) Act 1986.

\section{Experimental protocol}

Mice $(n=8)$ received twice-daily $(0930$ and 1630 h) s.c. injections of $\left[\mathrm{D}-\mathrm{Ala}^{2}\right] \mathrm{GIP}(1-30),\left[\mathrm{D}-\mathrm{Ala}^{2}\right] \mathrm{GIP}(1-42)$ (each at $25 \mathrm{nmol} / \mathrm{kg}$ body weight), or saline vehicle $(0.9 \%(\mathrm{w} / \mathrm{v})$, $\mathrm{NaCl}$ ) for 42 days. Food intake and body weight were recorded every 1-2 days, while plasma glucose and insulin concentrations were monitored at $1000 \mathrm{~h}$ twice weekly. At the end of the study, an i.p. glucose tolerance $(18 \mathrm{mmol} / \mathrm{kg}$ body weight) test and insulin sensitivity $(10 \mathrm{U} / \mathrm{kg}$ body weight) test were similarly performed at $1000 \mathrm{~h}$ in freely fed mice. The i.p. route was chosen as the method of glucose delivery, as this will bypass the stomach and intestines and so
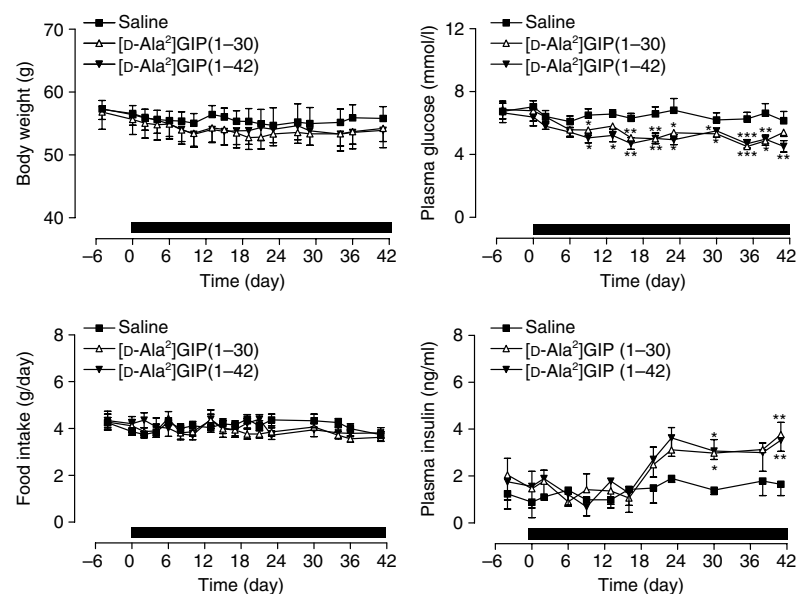

Figure 1 Effects of twice-daily [D-Ala $\left.{ }^{2}\right] \mathrm{GIP}(1-30)$ or [D-Ala $\left.{ }^{2}\right] \mathrm{GIP}(1-42)$ administration on body weight, food intake, plasma glucose and insulin concentrations in high-fat fed mice. Parameters were measured for 5 days prior to and 42 days during (indicated by black bar) treatment with saline vehicle, $\left[\mathrm{D}-\mathrm{Ala}{ }^{2}\right] \mathrm{GIP}(1-30)$ or $\left[\mathrm{D}-\mathrm{Ala}{ }^{2}\right] \mathrm{GIP}(1-42)$ (both at $25 \mathrm{nmol} / \mathrm{kg}$ body weight per day). Values are means \pm S.E.M. for eight mice. ${ }^{*} P<0 \cdot 05,{ }^{* *} P<0 \cdot 01$ and ${ }^{* * *} P<0 \cdot 001$ compared to saline control. 

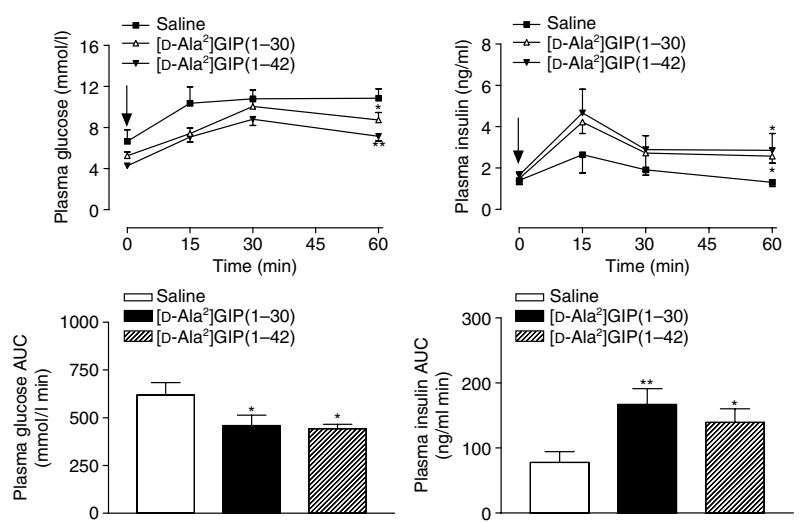

Figure 2 Effects of twice-daily [D-Ala $\left.{ }^{2}\right] \mathrm{GIP}(1-30)$ or [D-Ala $\left.{ }^{2}\right] \mathrm{GIP}(1-$ 42) administration on glucose tolerance and plasma insulin response to glucose in high-fat fed mice. Tests were conducted after twice-daily treatment with [D-Ala $\left.{ }^{2}\right] \mathrm{GIP}(1-30)$ or [D-Ala $\left.{ }^{2}\right] \mathrm{GIP}(1-42)$ (both at $25 \mathrm{nmol} / \mathrm{kg}$ body weight per day) for 42 days. Glucose (18 mmol/kg body weight) was administered by i.p. injection at the time indicated by the arrow. Plasma glucose and insulin AUC values for 0-60 min post injection are also shown. Values are means \pm S.E.M. for eight mice. ${ }^{*} P<0 \cdot 05$ and ${ }^{* *} P<0 \cdot 01$ compared to saline control.

does not stimulate release of the plethora of peptides and hormones involved in glucose regulation. Thus, the sole effects of $\left[\mathrm{D}-\mathrm{Ala}^{2}\right] \mathrm{GIP}(1-30)$ and $\left[\mathrm{D}-\mathrm{Ala}^{2}\right] \mathrm{GIP}(1-42)$ treatment on glucose uptake and transport in peripheral tissues can be more closely examined. On the days that plasma parameters were measured, the normal daily injection at $0930 \mathrm{~h}$ was delayed until blood sampling was complete.

\section{Biochemical analyses}

Blood samples were collected from the cut tip of the tail vein of conscious mice at the times indicated in the figures. Blood was immediately centrifuged using a Beckman microcentrifuge (Beckman Instruments, Galway, Ireland) for $30 \mathrm{~s}$ at $13000 \mathrm{~g}$. Plasma glucose was determined by an automated glucose oxidase procedure using a Beckman Glucose Analyzer II (Beckman Instruments). Plasma insulin was assayed using a modified dextran-coated charcoal RIA as described previously (Flatt \& Bailey 1981). Blood triglyceride and cholesterol levels were measured using a Hitachi Automated Analyser 912 (Boehringer).

\section{Measurement of indirect calorimetry, energy expenditure and locomotor activity}

Mice were placed in Complete Laboratory Animal Monitoring System (CLAMS) metabolic chambers (Columbus Instruments, Columbus, OH, USA) following the normal $0930 \mathrm{~h}$ daily injection. Consumption of $\mathrm{O}_{2}$ and production of $\mathrm{CO}_{2}$ were measured for $30 \mathrm{~s}$ at $15 \mathrm{~min}$ intervals for a total of $22 \mathrm{~h}$. Respiratory exchange ratio (RER) was calculated by dividing $\mathrm{VCO}_{2}$ by $\mathrm{VO}_{2}$. Energy expenditure was calculated using RER with the following equation $(3 \cdot 815+1 \cdot 232 \times$ RER) $\times \mathrm{VO}_{2}$. Ambulatory locomotor activity of each mouse was measured simultaneously using the optical beams (Opto M3, Columbus Instruments). Consecutive photo-beam breaks were scored as an ambulatory movement. Activity counts in $X$ - and $Z$-axes were recorded every minute for $22 \mathrm{~h}$. All measurements were carried out on day 42. Male mice were used to avoid influence of cyclical changes in female sex hormones on glucose homeostasis, but it should be noted that female rodents display increased activity levels compared to males (van Haaren et al. 1990).

\section{Statistical analyses}

Results are expressed as mean \pm S.E.M. Data were compared using ANOVA, followed by a Student-Newman-Keuls post hoc test. Area under the curve (AUC) analyses were calculated using the trapezoidal rule with baseline subtraction. $P<0 \cdot 05$ was considered to be statistically significant.
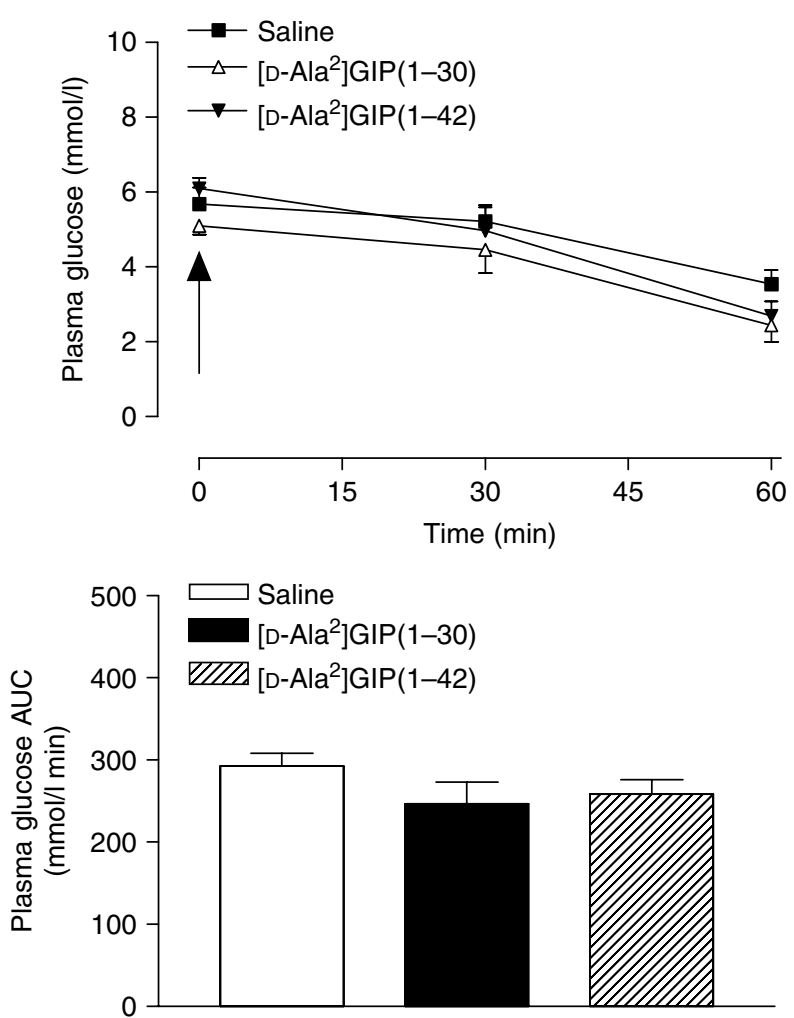

Figure 3 Effects of twice-daily [D-Ala $\left.{ }^{2}\right] \mathrm{GIP}(1-30)$ or $\left[\mathrm{D}-\mathrm{Ala}{ }^{2}\right] \mathrm{GIP}(1-$ 42) administration on insulin sensitivity in high-fat fed mice. Tests were conducted after twice-daily treatment with [D-Ala $\left.{ }^{2}\right] \mathrm{GIP}(1-30)$ or [D-Ala ${ }^{2}$ GIP(1-42) (both at $25 \mathrm{nmol} / \mathrm{kg}$ body weight per day) for 42 days. Insulin (10 U/kg body weight) was administered by i.p. injection at the time indicated by the arrow. AUC values for 0-60 min post injection are also shown. Values are means \pm s.E.M. for eight mice. 

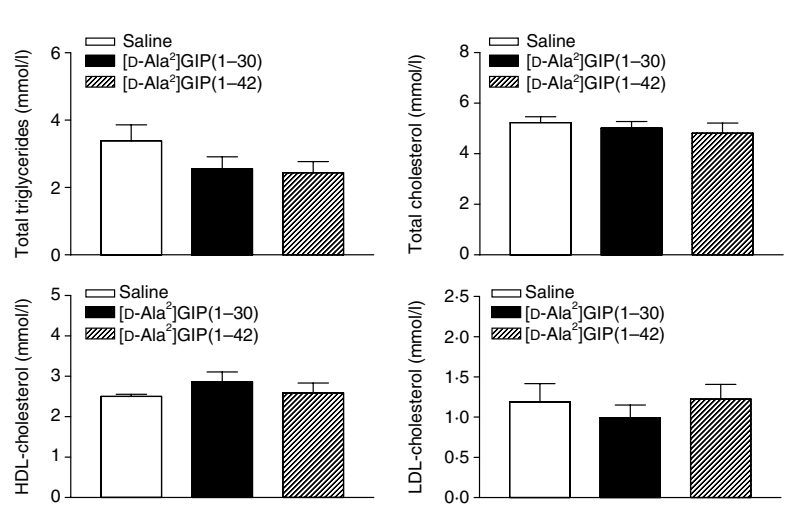

Figure 4 Effects of twice-daily [D-Ala $\left.{ }^{2}\right] \mathrm{GIP}(1-30)$ or [D-Ala $\left.{ }^{2}\right] \mathrm{GIP}(1-$ 42) administration on plasma lipid profile in high-fat fed mice. Parameters were measured after twice-daily treatment with [D-Ala ${ }^{2}$ GIP(1-30) or [D-Ala $\left.{ }^{2}\right]$ GIP(1-42) (both at $25 \mathrm{nmol} / \mathrm{kg}$ body weight per day) for 42 days. Values are mean \pm s.E.M. for eight mice.

\section{Results}

Effects of $\left[D-A l a^{2}\right] G I P(1-30)$ or $\left[D-A l a^{2}\right] G I P(1-42)$ on food intake, body weight and non-fasting plasma glucose and insulin concentrations in high-fat fed mice

Baseline characteristics of all experimental animals are shown in Table 1. Administration of $\left[\mathrm{D}-\mathrm{Ala}{ }^{2}\right] \mathrm{GIP}(1-30)$ or $\left[\mathrm{D}-\mathrm{Ala}^{2}\right] \mathrm{GIP}(1-42)$ had no effect on food intake or body weight compared to saline-treated controls over the 42-day period (Fig. 1). However, non-fasted plasma glucose concentrations were significantly $(P<0.05$ to $P<0 \cdot 001)$ decreased at numerous observation points throughout the study in all GIP-treated mice (Fig. 1). In agreement with this, plasma insulin levels were significantly $(P<0.05$ to $P<0 \cdot 01)$ elevated by day 30-42 in [D-Ala $\left.{ }^{2}\right]$ GIP $(1-30)-$ and $\left[\mathrm{D}-\mathrm{Ala}{ }^{2}\right] \mathrm{GIP}(1-42)-$ treated mice compared to controls (Fig. 1).

Effects of $\left[D-A l a^{2}\right] G I P(1-30)$ or $\left[D-A l a^{2}\right] G I P(1-42)$ on glucose tolerance and insulin sensitivity in high-fat fed mice

As shown in Fig. 2, administration of $\left[\mathrm{D}-\mathrm{Ala}^{2}\right] \mathrm{GIP}(1-30)$ or $\left[\mathrm{D}-\mathrm{Ala}^{2}\right] \mathrm{GIP}(1-42)$ for 42 days significantly improved individual $60 \mathrm{~min}$ post injection values $(P<0.01$ and $P<0 \cdot 05$ respectively) and the $0-60 \mathrm{~min}$ overall glycaemic excursion $(P<0 \cdot 05)$ values following an i.p. glucose load (Fig. 2). There was a strong tendency for improvements in glycaemic levels in both GIP-treated groups at 0, 15 and $30 \mathrm{~min}$ post injection; however, despite the lack of data variability, these responses failed to reach significance. The insulinotropic responses were significantly $(P<0.05$ to $P<0 \cdot 01)$ elevated in terms of individual and overall AUC values in both GIP-treated groups when compared to controls (Fig. 2). However, insulin sensitivity was not significantly different between any of the groups (Fig. 3).
Effects of $\left[D-A l a^{2}\right] G I P(1-30)$ or $\left[D-A l a^{2}\right] G I P(1-42)$ on plasma lipid profile in high-fat fed mice

Administration of $\left[\mathrm{D}-\mathrm{Ala}^{2}\right] \mathrm{GIP}(1-30)$ or $\left[\mathrm{D}-\mathrm{Ala}{ }^{2}\right] \mathrm{GIP}(1-42)$ for 42 days in high-fat fed mice was not associated with any significant changes in plasma total cholesterol, low density lipoprotein-cholesterol, high density lipoprotein-cholesterol or triglyceride levels, despite the lack of data variability, when compared to saline-treated controls (Fig. 4).

\section{Effects of $\left[D-A l a^{2}\right] G I P(1-30)$ or $\left[D-A l a^{2}\right] G I P(1-42)$ on locomotor activity in high-fat fed mice}

Figure 5 depicts the effects of 42 days treatment with $\left[\mathrm{D}-\mathrm{Ala}^{2}\right] \mathrm{GIP}(1-30)$ or $\left[\mathrm{D}-\mathrm{Ala}^{2}\right] \mathrm{GIP}(1-42)$ on locomotor activity. Both peptides significantly $(P<0 \cdot 05)$ increased ambulatory activity in high-fat fed mice as assessed by $\mathrm{X}$ beam breaks during the light phase (Fig. 5). However, there were no significant differences in ambulatory activity between control and treatment groups during the dark phase (Fig. 5). In addition, there were no significant differences in rearing or jumping episodes during the light or dark phase, as assessed by $\mathrm{Z}$ beam breaks, in $\left[\mathrm{D}-\mathrm{Ala}{ }^{2}\right] \mathrm{GIP}(1-30)$ - or $\left[\mathrm{D}-\mathrm{Ala}^{2}\right]-$ GIP(1-42)-treated mice when compared to controls (Fig. 5). Notably, activity levels of high-fat control mice had a tendency to be decreased compared to lean control counterparts (data not shown).

Effects of $\left[D-A l a^{2}\right] G I P(1-30)$ or $\left[D-A l a^{2}\right] G I P(1-42)$ on indirect calorimetry and energy expenditure in high-fat fed mice

Administration of $\left[\mathrm{D}-\mathrm{Ala}^{2}\right] \mathrm{GIP}(1-30)$ or $\left[\mathrm{D}-\mathrm{Ala}{ }^{2}\right] \mathrm{GIP}(1-42)$ had no significant effect on $\mathrm{O}_{2}$ consumption or $\mathrm{CO}_{2}$ production when compared to controls (Fig. 6). Similarly,
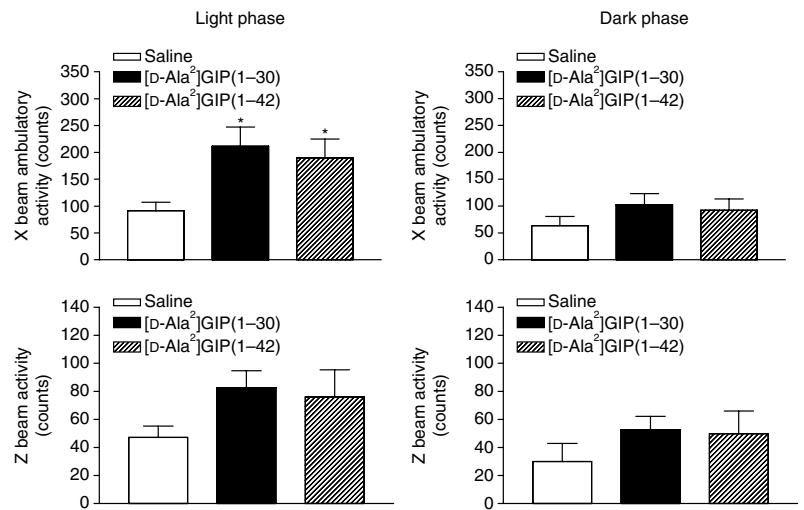

Figure 5 Effects of twice-daily [D-Ala $\left.{ }^{2}\right] \mathrm{GIP}(1-30)$ or [D-Ala $\left.{ }^{2}\right] \mathrm{GIP}(1-$ 42) administration on locomotor activity in high-fat fed mice. Parameters were measured after twice-daily treatment with [D-Ala ${ }^{2}$ GIP(1-30) or [D-Ala ${ }^{2}$ GIP(1-42) (both at $25 \mathrm{nmol} / \mathrm{kg}$ body weight per day) for 42 days. Mice were placed in CLAMS metabolic chambers, and locomotor activity was measured using optical beams. Activity counts in $X$ - and $Z$-axes were recorded every minute for $22 \mathrm{~h}$. Values are means \pm s.E.M. for six mice. ${ }^{*} P<0.05$ compared to saline control. 

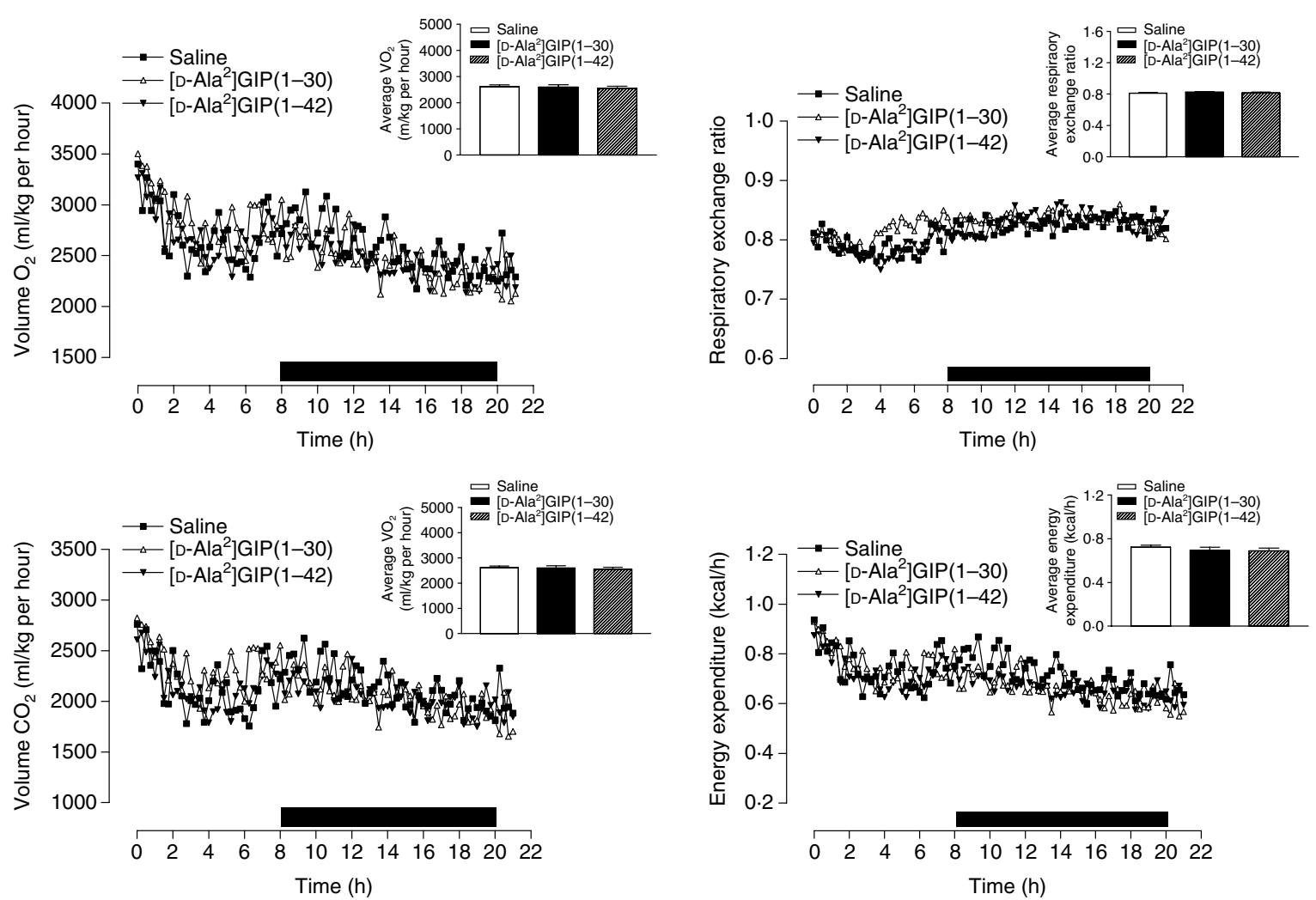

Figure 6 Effects of twice-daily $\left[\mathrm{D}-\mathrm{Ala}{ }^{2}\right] \mathrm{GIP}(1-30)$ or $\left[\mathrm{D}-\mathrm{Ala}{ }^{2}\right] \mathrm{GIP}(1-42)$ administration on $\mathrm{O}_{2}$ consumption, $\mathrm{CO}_{2}$ production, respiratory exchange ratio and energy expenditure. Parameters were measured after twice-daily treatment with $\left[\mathrm{D}-\mathrm{Ala} \mathrm{a}^{2}\right] \mathrm{GIP}(1-30)$ or

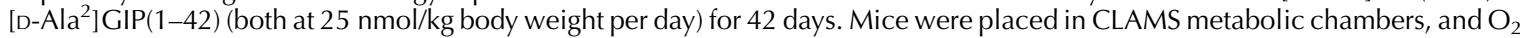
consumption or $\mathrm{CO}_{2}$ production were measured for $30 \mathrm{~s}$ at 15 min intervals. RER was calculated by dividing $\mathrm{VCO}_{2}$ by $\mathrm{VO}_{2}$. Energy expenditure was calculated using RER with the following Default $(3 \cdot 815+1 \cdot 232 \times \mathrm{RER}) \times \mathrm{VO}_{2}$. The dark phase is indicated by the black horizontal bar. Insets depict the consequence of combining light and dark phase data. Values are means \pm s.E.M. for six mice.

RER and energy expenditure were not significantly altered in terms of individual measurements or overall responses during the $22 \mathrm{~h}$ observation period in mice treated with $\left[\mathrm{D}-\mathrm{Ala}{ }^{2}\right] \mathrm{GIP}(1-30)$ or $\left[\mathrm{D}-\mathrm{Ala}^{2}\right] \mathrm{GIP}(1-42)$ (Fig. 6).

\section{Discussion}

In agreement with previous studies, twice-daily injection of high-fat fed mice with long-acting GIP receptor agonists had no adverse or toxic effects (Irwin \& Flatt 2009a). Food intake and body weight were similar to saline-treated control mice, consistent with other feeding studies in rodents (Irwin \& Flatt 2009a, Kerr et al. 2009, McIntosh et al. 2009). As would be expected, a major benefit of twice-daily injection of GIP peptides centred on increased insulin section (Irwin \& Flatt $2009 a)$. Thus, both $\left[\mathrm{D}-\mathrm{Ala}^{2}\right] \mathrm{GIP}(1-30)-$ and $\left[\mathrm{D}-\mathrm{Ala}^{2}\right]-$ GIP(1-42)-treated mice exhibited significantly elevated plasma insulin concentrations compared to controls in both the non-fasted state and following administration of glucose. This was associated with decreased plasma glucose levels and improved i.p. glucose tolerance. Protective effects of GIP receptor signalling on islet survival as well as function may also contribute, since insulin sensitivity was unaltered. For example, 4-day administration of [D-Ala $\left.{ }^{2}\right] \mathrm{GIP}(1-30)$ afforded partial protection of $\beta$-cell destruction in streptozotocintreated rats, resulting in greater glycaemic control and insulin responses (Widenmaier et al. 2010). This appeared to be a result of decreased apoptosis rather than enhanced $\beta$-cell proliferation. Importantly, in the present study, there were no observed differences between the beneficial effects of GIP(1-30) and GIP(1-40). Thus, the stable forms [D-Ala ${ }^{2}$ ] GIP(1-30) and $\left[\mathrm{D}-\mathrm{Ala}^{2}\right] \mathrm{GIP}(1-42)$ were equally effective in restoring glycaemic control and promoting insulin secretion in high-fat fed mice. This provides conclusive evidence that the truncated GIP form, GIP(1-30), contains the essential structural motifs for full GIP receptor binding and activation. Furthermore, the relative potency of $\left[\mathrm{D}-\mathrm{Ala}{ }^{2}\right] \mathrm{GIP}(1-30)$ and $\left[\mathrm{D}-\mathrm{Ala}{ }^{2}\right] \mathrm{GIP}(1-42)$ could possibly be improved by conjugation to a fatty acid or polyethylene glycol molecule to impede renal filtration.

Although extensive studies have been conducted on $\beta$-cell secretory function and potential antidiabetic actions of long-acting forms of GIP(1-42) (Irwin \& Flatt 2009a, 
Irwin et al. 2010), there is a paucity of information on their possible effects on locomotor activity and energy expenditure. To date, a modest increase in motor activity has been reported in mice treated sub-chronically with the specific GIP receptor antagonist $\left(\mathrm{Pro}^{3}\right)$ GIP (McClean et al. 2007, 2008) and in GIP receptor knockout mice (Hansotia et al. 2007). Interestingly, $\left[\mathrm{D}-\mathrm{Ala}^{2}\right] \mathrm{GIP}(1-30)-$ and $\left[\mathrm{D}-\mathrm{Ala}^{2}\right] \mathrm{GIP}$ (1-42)-treated mice also displayed significantly increased locomotor activity during the light phase in the current study. The reason why similar effects are observed with compromised as well as enhanced GIP receptor activation needs further study. However, the observations in the current study are interesting given that locomotor activity of mice is normally much less during light as opposed to the dark phase. Furthermore, studies in our laboratory indicate that motor activity of high-fat fed mice is somewhat reduced compared to lean counterparts. Thus, $\left[\mathrm{D}-\mathrm{Ala}^{2}\right] \mathrm{GIP}(1-30)$ and $\left[\mathrm{D}-\mathrm{Ala}^{2}\right] \mathrm{GIP}(1-42)$ treatment may partially reverse this consequence of high-fat feeding.

GIP receptor knockout mice exhibit a significant reduction of respiratory quotient during the light phase, but in agreement with the current study, modulation of GIP receptor signalling did not evoke changes in oxygen consumption (Miyawaki et al. 2002). Furthermore, since GIP has well-documented lipogenic actions that are potentially involved in the promotion of obesity (Irwin \& Flatt 2009b), the lack of effect on RER could be one explanation for the weight neutral effects of the GIP peptides. Importantly, the truncated analogue $\left[\mathrm{D}-\mathrm{Ala}^{2}\right] \mathrm{GIP}(1-30)$ had similar effects to $\left[\mathrm{D}-\mathrm{Ala}^{2}\right] \mathrm{GIP}(1-42)$ on all parameters relating to locomotor activity and energy expenditure. Similarly, the plasma lipid profile was not different between the two groups of treated mice. Recent studies in 3T3-L1 adipocytes suggested that GIP(1-30) was significantly less potent in stimulating lipoprotein lipase activity than GIP(1-42) (Widenmaier et al. 2010). The present results imply that such observations are not translated functionally to the in vivo setting. This could be due to a high level of redundancy in GIP receptor signalling in adipocytes or other, as yet unknown, metabolic adaptations as a result of sustained GIP receptor activation. Furthermore, it appears that if GIP(1-30) is released by a sub-population of intestinal $\mathrm{K}$-cells, or even pancreatic $\alpha$-cells, the effects of this truncated form would be similar to GIP(1-42). Nevertheless, GIP exerts effects on brain, bone and possibly cardiac tissue (McIntosh et al. 2009, Irwin et al. 2010), and the possibility of different responses to these two naturally occurring forms of GIP in these tissues necessitates further study.

In conclusion, the present study has characterised the bioactivity of DPP IV-resistant $\left[\mathrm{D}-\mathrm{Ala}^{2}\right] \mathrm{GIP}(1-30)$ and $[\mathrm{D}-$ $\left.\mathrm{Ala}^{2}\right] \mathrm{GIP}(1-42)$. The results demonstrate that the truncated and full-length forms of GIP exhibit essentially similar beneficial effects on metabolic control and energy expenditure in high-fat fed mice. Whether the enhanced activity levels observed following $\left[\mathrm{D}-\mathrm{Ala}^{2}\right] \mathrm{GIP}(1-30)$ and $\left[\mathrm{D}-\mathrm{Ala}^{2}\right] \mathrm{GIP}(1-42)$ administration will impact on their usefulness as therapeutic agents remains to be elucidated. In addition, further studies are needed to delineate whether subtle differences exist between their biological activities, particularly at other GIP receptor expressing sites not examined in the current study.

\section{Declaration of interest}

VAG, NI and PRF hold shares with Diabetic Ltd.

\section{Funding}

These studies were supported by the SAAD Trading and Contracting Company and the Department of Education and Learning, Northern Ireland.

\section{References}

Deacon CF, Plamboeck A, Rosenkilde MM, de Heer J \& Holst JJ 2006 GIP-(3-42) does not antagonize insulinotropic effects of GIP at physiological concentrations. American Journal of Physiology. Endocrinology and Metabolism 291 E468-E475. (doi:10.1152/ajpendo. 00577.2005)

Flatt PR \& Bailey CJ 1981 Abnormal plasma glucose and insulin responses in heterozygous lean $(\mathrm{ob} /+$ ) mice. Diabetologia 20 573-577. (doi:10.1007/ BF00252768)

Fujita Y, Asadi A, Yang GK, Kwok YN \& Kieffer TJ 2010a Differential processing of pro-glucose-dependent insulinotropic polypeptide in gut. American Journal of Physiology. Gastrointestinal and Liver Physiology 298 G608-G614. (doi:10.1152/ajpgi.00024.2010)

Fujita Y, Wideman RD, Asadi A, Yang GK, Baker R, Webber T, Zhang T, Wang R, Ao Z, Warnock GL et al. 2010 b Glucose-dependent insulinotropic polypeptide is expressed in pancreatic islet $\alpha$-cells and promotes insulin secretion. Gastroenterology 138 1966-1975. (doi:10.1053/ j.gastro.2010.01.049)

van Haaren F, van Hest A \& Heinsbroek RP 1990 Behavioral differences between male and female rats: effects of gonadal hormones on learning and memory. Neuroscience and Biobehavioral Reviews 14 23-33. (doi:10.1016/ S0149-7634(05)80157-5)

Hansotia T, Maida A, Flock G, Yamada Y, Tsukiyama K, Seino Y \& Drucker DJ 2007 Extrapancreatic incretin receptors modulate glucose homeostasis, body weight, and energy expenditure. Journal of Clinical Investigation 117 143-152. (doi:10.1172/JCI25483)

Hinke SA, Gelling RW, Pederson RA, Manhart S, Nian C, Demuth HU \& McIntosh CH 2002 Dipeptidyl peptidase IV-resistant [D-Ala(2)]glucosedependent insulinotropic polypeptide (GIP) improves glucose tolerance in normal and obese diabetic rats. Diabetes 51 652-661. (doi:10.2337/diabetes. 51.3.652)

Irwin N \& Flatt PR 2009a Therapeutic potential for GIP receptor agonists and antagonists. Best Practice and Research. Clinical Endocrinology and Metabolism 23 499-512. (doi:10.1016/j.beem.2009.03.001)

Irwin N \& Flatt PR $2009 b$ Evidence for beneficial effects of compromised gastric inhibitory polypeptide action in obesity-related diabetes and possible therapeutic implications. Diabetologia 52 1724-1731. (doi:10.1007/s00125009-1422-8)

Irwin N, Gault V \& Flatt PR 2010 Therapeutic potential of the original incretin hormone glucose-dependent insulinotropic polypeptide: diabetes, obesity, osteoporosis and Alzheimer's disease? Expert Opinion on Investigational Drugs 19 1039-1048. (doi:10.1517/13543784.2010.513381)

Kerr BD, Irwin N, O'Harte FP, Bailey CJ, Flatt PR \& Gault VA 2009 Fatty acid derivatised analogues of glucose-dependent insulinotropic 
polypeptide with improved antihyperglycaemic and insulinotropic properties. Biochemical Pharmacology 78 1008-1016. (doi:10.1016/j.bcp. 2009.05.037)

Maida A, Hansotia T, Longuet C, Seino Y \& Drucker DJ 2009 Differential importance of glucose-dependent insulinotropic polypeptide vs glucagonlike peptide 1 receptor signaling for $\beta$ cell survival in mice. Gastroenterology 137 2146-2157. (doi:10.1053/j.gastro.2009.09.004)

McClean PL, Irwin N, Cassidy RS, Holst JJ, Gault VA \& Flatt PR 2007 GIP receptor antagonism reverses obesity, insulin resistance, and associated metabolic disturbances induced in mice by prolonged consumption of high-fat diet. American Journal of Physiology. Endocrinology and Metabolism 293 E1746-E1755. (doi:10.1152/ajpendo.00460.2007)

McClean PL, Irwin N, Hunter K, Gault VA \& Flatt PR 2008 (Pro(3))GIP[mPEG]: novel, long-acting, mPEGylated antagonist of gastric inhibitory polypeptide for obesity-diabetes (diabesity) therapy. British Journal of Pharmacology 155 690-701. (doi:10.1038/bjp.2008.317)

McIntosh CH, Widenmaier S \& Kim SJ 2009 Glucose-dependent insulinotropic polypeptide (gastric inhibitory polypeptide; GIP). Vitamins and Hormones 80 409-471.

Miyawaki K, Yamada Y, Ban N, Ihara Y, Tsukiyama K, Zhou H, Fujimoto S, Oku A, Tsuda K, Toyokuni S et al. 2002 Inhibition of gastric inhibitory polypeptide signaling prevents obesity. Nature Medicine 8 738-742. (doi:10. 1038/nm727)
Pederson RA \& Brown JC 1976 The insulinotropic action of gastric inhibitory polypeptide in the perfused isolated rat pancreas. Endocrinology 99 780-785. (doi:10.1210/endo-99-3-780)

Pederson RA, Mochizuki T, Yanaihara C, Yanaihara N \& Brown JC 1990 Reduced somatostatinotropic effect of a GIP fragment \{pGIP(1-30)NH2\} with insulinotropic activity. Digestion 4686.

Ugleholdt R, Poulsen ML, Holst PJ, Irminger JC, Orskov C, Pedersen J, Rosenkilde MM, Zhu X, Steiner DF \& Holst JJ 2006 Prohormone convertase $1 / 3$ is essential for processing of the glucose-dependent insulinotropic polypeptide precursor. Journal of Biological Chemistry 281 11050-11057. (doi:10.1074/jbc.M601203200)

Widenmaier SB, Kim SJ, Yang GK, De Los Reyes T, Nian C, Asadi A, Seino Y, Kieffer TJ, Kwok YN \& McIntosh CH 2010 A GIP receptor agonist exhibits $\beta$-cell anti-apoptotic actions in rat models of diabetes resulting in improved $\beta$-cell function and glycemic control. PLoS ONE 5 e9590. (doi:10.1371/journal.pone.0009590)
Received in final form 22 December 2010
Accepted 6 January 2011
Made available online as an Accepted Preprint 6 January 2011 